\title{
Assessing the Impact of Land-Use Land-Cover Change on Stream Water and Sediment Yields at a Watershed Level Using SWAT
}

\author{
Wubishet Tadesse ${ }^{1}$, Stephanie Whitaker ${ }^{2}$, William Crosson ${ }^{3}$, Constance Wilson ${ }^{4}$ \\ ${ }^{1}$ Department of Biological and Environmental Sciences, Alabama A \& M University, Huntsville, AL, USA \\ ${ }^{2}$ Tennessee Department of Environment and Conservation, Nashville, TN, USA \\ ${ }^{3}$ National Space Science and Technology Center, Universities Space Research Association, Huntsville, AL, USA \\ ${ }^{4}$ Department of Community and Regional Planning, Alabama A \& M University, Huntsville, AL, USA \\ Email: wubishet.tadesse@aamu.edu
}

Received 10 April 2015; accepted 4 July 2015; published 7 July 2015

Copyright (C) 2015 by authors and Scientific Research Publishing Inc.

This work is licensed under the Creative Commons Attribution International License (CC BY).

http://creativecommons.org/licenses/by/4.0/

(c) (i) Open Access

\begin{abstract}
Flint River watershed is located in northern Alabama and southern Tennessee, USA and is home to several species of rare, threatened, or endangered plants and animals in a rapidly urbanizing area. Dominant land uses are forest and agricultural, with row crops and livestock production as major farm enterprises. Soil and Water Assessment Tool (SWAT), a deterministic hydrologic model that can predict hydrologic conditions over various temporal and spatial scales, was used to simulate the hydrologic response of the watershed to land-use/land cover (LULC) change. Analysis between observed and predicted stream flow demonstrated that the initial SWAT model run requires calibration of stream parameters in order to give a more accurate output from the model. The calibration was performed with sequential uncertainty fitting, ver. 2 (SUFI-2) in the SWAT Calibration Uncertainty Program. After calibration, stream sediment yield values were compared by sub-basin between a current (2001) and three future (2030) land use scenarios, in order to identify areas in the watershed that were the most susceptible to increased sediment yield in the future. The future growth scenarios (smart, plan and sprawl) were created using the ArcGIS extension, Prescott Spatial Growth Model. Sub-basins with the greatest sensitivity for larger sediment yields were identified and prioritized for conservation efforts.
\end{abstract}

\section{Keywords}

SWAT, Sediment Yield, Prescott Spatial Growth Model, LULC

How to cite this paper: Tadesse, W., Whitaker, S., Crosson, W. and Wilson, C. (2015) Assessing the Impact of Land-Use Land-Cover Change on Stream Water and Sediment Yields at a Watershed Level Using SWAT. Open Journal of Modern Hydrology, 5, 68-85. http://dx.doi.org/10.4236/ojmh.2015.53007 


\section{Introduction}

Land use/land cover (LULC) plays a vital role in water transport in the hydrologic cycle and primarily aids in reducing overland flows. Due to its effect on evaporation, transpiration and solar radiation interception, LULC is a driving factor in the energy balance within the hydrologic cycle [1]. The hydrology of local watersheds can vary drastically and water quality as well as water flow patterns is often dependent on a combination of soil, LULC and elevation characteristics unique to the area. For example, as forested area is lost and developed land expands it has shown to reduce base flow and/or an increase in soil erosion generally occurs [2]. Soil erosion by water is one of the main mechanisms of land degradation worldwide [3]. Within the Flint River Watershed (FRW) the largest increase in land use has been in urban area and the highest reduction has been in agricultural and forested areas [4]. High proportions of impervious surfaces can lead to increases in nutrient and sediment loading into streams [5], bacterial loading [6], and stream temperature increase [7]. Increases in nutrient, temperature, and sediment depositions are detrimental to aquatic fauna and the habitat structure upon which they depend.Fish spawning and mussel beds can be rendered unusable by deposited sediments [8]. Sediments can also carry Escherichia coli (E. coli) and Salmonella from pastures [5] or failing septic tanks, increasing the risk of contamination of local drinking water and recreational areas causing potential threat to human health [9]. As a result of LULC change over the years, the water quality of the FRW has been degraded in certain areas [4]. As stated in the management plan, the primary issues of the watershed are uncontrolled urban sprawl and associated water quality and habitat degradation; hydrologic alteration of the river due to stormwater from increased impervious surfaces, water withdrawals, and other impacts including increased intensity and frequency of flooding and loss of base flows [4]. The plan has not been revised since May 2008 therefore, new research information on the FRW needs to be implemented to update the watershed management plan.

Studies have analyzed the effects of LULC change on hydrological fluxes in watersheds (e.g. [10]-[13]). Most of these studies analyze the effect of LULC change on the water balance without considering that a change in LULC may also induce a change in soil erosion sources and quantities. Recently, many studies have been launched to predict the hydrologic response of varying scenarios of land use modification through the application of multiple models [14] [15]. These research efforts have proven useful for planners and policy makers as a form of decision support for evaluating urbanized watersheds. This study examined future land use scenarios in the FRW relative to their impact on surface-water quality, e.g. discharge and sediment yield, using the hydrologic model Soil and Water Assessment Tool (SWAT) [16]. The future land use scenarios: smart growth, plan trend and sprawl growth; produced for the study area were created using the Prescott Spatial Growth Model (PSGM) which is an extension in ArcGIS 9.3. The objective of the research was to identify sensitive areas that may be affected by increases in sediment yield from land use change, such as conversion of agricultural land to urbanization by using an integrated approach.

This study used this approach and applied multiple PSGM and SWAT models in order to make predictions on fine spatial and temporal scales. Knowing how the FRW responds to urbanization is significant to develop better management practices and planning decisions in the future. A specific research question that can be answered as a result of this study is how increases in urbanization or changes in LULC affect the spatial and temporal variability of discharge and sediment loading in the FRW. From this we can determine what sub-basins may become sensitive in the future due to increases in developed land.

\section{Description of SWAT}

SWAT is a physically-based and semi-distributed river basin or watershed-scale model developed to predict the impact of land management practices on sediment, water, and agricultural chemical yields on complex watersheds with varying land use, soils, and management conditions over long spans of time [17]. SWAT was developed in the early 1990s for the USDA Agricultural Research Services (ARS). SWAT has been updated to the most recent version, ArcSWAT 2012 [16] which is an ArcGIS 10.x extension. This interface streamlines data entry, the creation of required input files and parameter editing, all while allowing spatial parameters to be easily observed in the ArcGIS environment. In ArcSWAT, the watershed is delineated into a number of sub-basins, which are further divided into Hydrological Response Units (HRUs) that consist of homogeneous land use, management, and soil characteristics. The HRUs represent percentages of the sub-watershed area and are not identified spatially within a simulation [18]. Subdividing the watershed into HRUs enables the model to reflect 
differences in evapotranspiration and other hydrologic conditions for different land covers and soils. Runoff is predicted separately for each HRU and routed to obtain the total runoff for the watershed which increases the accuracy of load predictions [16]. By delineating the watershed, the user is able to reference different areas of the watershed to one another spatially. For each sub-basin input, information is grouped into the following categories: climate; groundwater; HRUs; ponds/wetlands; and the main channel draining the sub-basin [19].

Water balance is the driving force behind everything that happens in the watershed. As simulated by the model, the hydrologic cycle must conform to what is happening in the watershed to accurately predict movement of sediments [19]. The hydrology is simulated in two major ways: 1) the Land Phase, which controls sediment, nutrient and pesticides loading to each channel from sub-basins, and 2) the Water or Routing Phase that controls the movement through the channel network to the watershed outlet [19]. The SWAT soil-water routing feature is calculated from the interaction of four main pathways: soil evaporation, plant uptake and transpiration, lateral flow and percolation. Sediment yield in SWAT is estimated with the modified soil loss equation (MUSLE) developed by [20]. The hydrologic cycle is simulated by SWAT based on the following water balance equation [17].

$$
S W_{t}=S W_{0}+\sum\left(R_{\text {day }}-Q_{\text {surf }}-E_{a}-W_{\text {sweep }}-Q_{g w}\right)
$$

where:

- $t$ is the time in days

- $S W_{t}$ is the soil water content at time $\mathrm{t}(\mathrm{mm})$

- $S W_{0}$ is the initial soil water content (mm)

- $R_{\text {day }}$ is amount of precipitation on day $i(\mathrm{~mm})$

- $Q_{\text {surf }}$ is the amountof surface runoff on day $i(\mathrm{~mm})$

- $E_{a}$ is the amount of evapotranspiration on day $i(\mathrm{~mm})$

- $w_{\text {sweep }}$ is the amount of water entering the vadose zone from the soil profile on day $i(\mathrm{~mm})$

- $Q_{g w}$ is the amount of return flow on day $i(\mathrm{~mm})$

SWAT was chosen for the compatibility of available data and software and for its complex representation of fine spatial scales. Moreover, SWAT has become popular among environmental managers since it has been adopted as a component of the US Environmental Protection Agency's Better Assessment Science Integrating Point and Non Point Sources (BASINS) software packages [21]. SWAT has shown to be successful for land-use change assessments and has generated an expanding body of research projects. SWAT has also been extensively validated across the US for stream-flow and sediment loads [22]. Many researchers have utilized SWAT in their research questions in other countries including India [23] [24], and New Zealand [25]. Strong emphasis on vegetation and hydrological interactions within SWAT make it a preferable model for this land-use based hydrological analysis.

\section{Materials and Methods}

\subsection{Study Area}

The Flint River watershed (Hydrologic Unit Code: 06030002) encompasses approximately 1445 Square km in Madison County, Alabama, and Lincoln County, Tennessee (Figure 1). The majority of the watershed is in Madison County and drains into the Tennessee River from which the City of Huntsville, Alabama receives its public drinking water. There are nine water bodies within the FRW currently listed on the EPA 303(d) impaired water quality list [26]. The general land uses in the watershed are (with areas in $\mathrm{km}^{2}$ and $\%$ of watershed): Forest 425 (30\%), Cropland 360 (25\%), Pasture 400 (28\%), Mixed 120 (8\%) and Urban 120 (8\%), which is increasing by $19 \mathrm{~km}^{2} /$ year (1.5\%) [4]. The temperature and precipitation within the watershed vary considerably throughout the year. The average annual temperature is $62.6^{\circ} \mathrm{F}\left(17^{\circ} \mathrm{C}\right)$, with an average mean daily temperature of $39.8^{\circ} \mathrm{F}\left(4.3^{\circ} \mathrm{C}\right)$ in January to $80.2^{\circ} \mathrm{F}\left(26.7^{\circ} \mathrm{C}\right)$ in July. Alabama receives approximately 1397 millimeters of rainfall each year, but on average, only 152.4 millimeters goes underground to become ground-water recharge [27].

Soils in the watershed have a mesic or thermic temperature regime, are well drained, highly acidic, leached and have clay-enriched subsoil. More than a million tons of sediment is transported each year from many different sources [4]. The estimated yearly sediment loads from erosion are substantial: 205,909 tons of sediment is eroded from stream banks [4].

Madison County is one of the fastest growing counties in Alabama having grown from a population of 


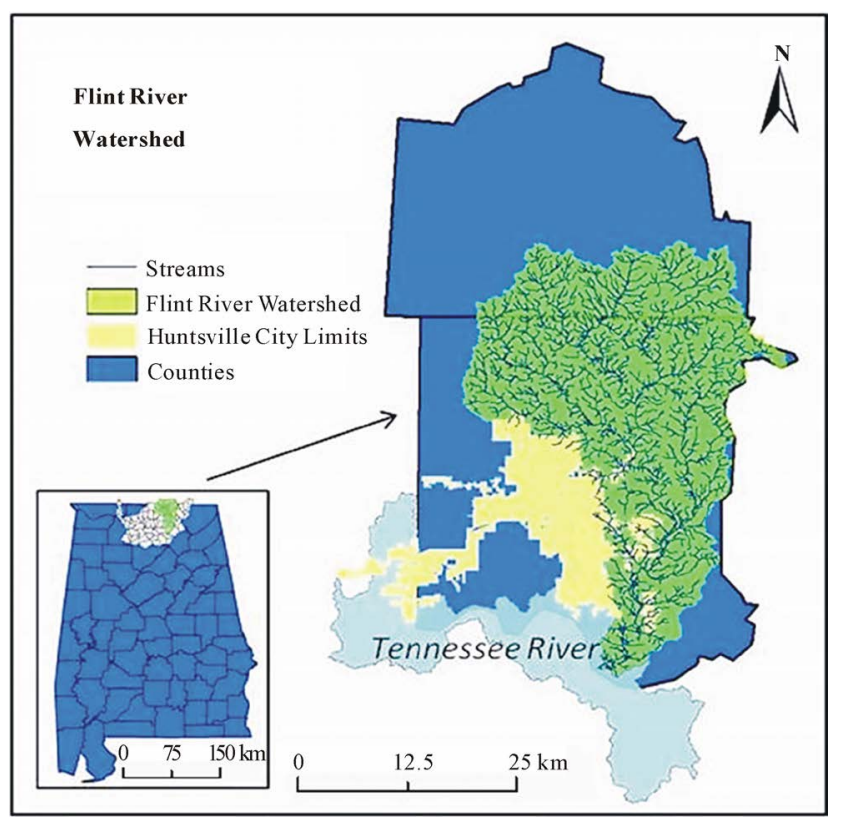

Figure 1. Map depicting the spatial orientation of the Flint River watershed.

238,912 in 1990 to 327,744 in 2009 [28]. The County's land use is over 30\% urban in many of the Flint River's sub-watersheds, and is estimated that by 2020 , more than $50 \%$ of the county will be developed for urban use, reaching far into the FRW [29]. The growing population is placing heavy and divergent demands on the FRW. For example, the National Land Cover Dataset (NLCD) change between 1992 and 2006 shows how much the watershed has been developed in just 14 years. Urban land cover within the FRW increased from $0.98 \%$ in 1992 to $8.7 \%$ in 2006 with most development occurring around existing roads.

\subsection{Future Spatial Growth Scenarios}

Scenarios, as defined by the Intergovernmental Panel on Climate Change [30], are, "plausible and often simplified descriptions of how the future may develop based on a coherent and internally consistent set of assumptions about driving forces and key relationships". Scenario analysis is accomplished by using a process model and land-use data to produce a representation of the physical manifestations of scenario characteristics. The PSGM was developed at Prescott College (AZ) in collaboration with NASA and is a dynamic process model with a raster-based structure. The PSGM is an ArcGIS 9.x compatible application that assigns future growth into available land based on user-defined parameters [31]. The model allows users to build different future growth scenarios based on socio-economic projections such as population, employment and other controlling factors. The PSGM is a grid-based model that is projective, not predictive. The PSGM has been previously validated and used in other studies to model growth projections for various counties in the Atlanta, Georgia region [31].

The three different alternative-future scenarios produced by the PSGM in this analysis are smart growth, plan trend, and sprawl growth. The smart growth places greater priority on ecosystem protection and restoration, although still reflecting a plausible balance between ecological, social, and economic considerations. Plan trend assumes existing land use plans are implemented as written, with few exceptions, and recent trends continue. The sprawl growth, which has the least conservation, assumes current land use policies are relaxed and has a greater reliance on land and water use [32]. The future scenarios for the FRW were created using the baseline National Land Cover Dataset (NLCD) for 2001 observed data and built upon to portray land use in the year 2030. The initial land cover output was for both Lincoln County, Tennessee and Madison County, Alabama (Figure 2) but was extracted using the FRW boundary and used as an input into the SWAT model. The difference between the baseline land cover (NLCD 2001) and the future growth scenarios (sprawl growth, plan trend, and smart growth) can easily be detected in Figure 2. The numerical result is also given in Table 1.This table shows percent of land base composed of water, urban, forest, range, pasture, agriculture, and wetland. The three 

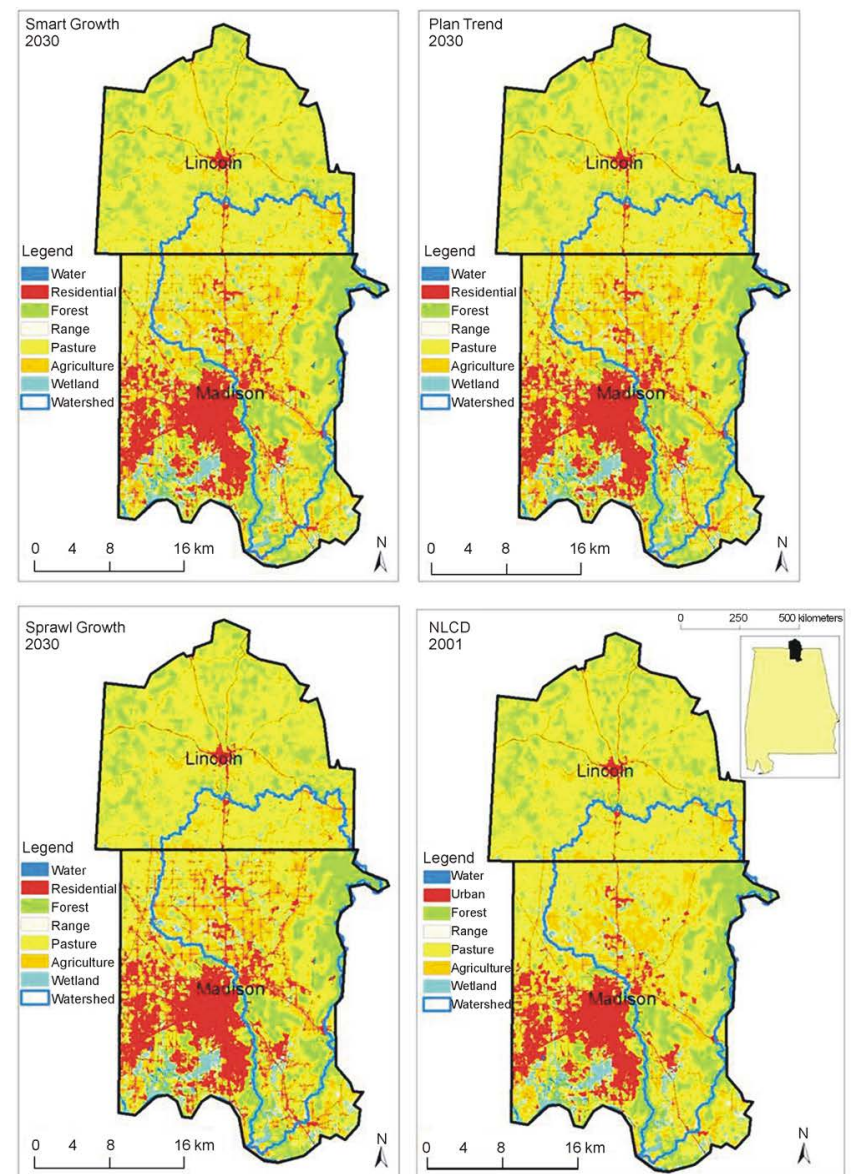

Figure 2. The three future growth scenarios and baseline land cover for Lincoln County, Tennessee and Madison County, Alabama.

Table 1. Percent of total area and percent relative change of land cover for the dominate land uses in the River watershed (+values indicate an increment from baselione conditions).

\begin{tabular}{ccccc}
\hline \multirow{2}{*}{ Land cover } & \multicolumn{4}{c}{ Percent total area and percent change } \\
\cline { 2 - 5 } & Baseline & Smart & Plan & Sprawl \\
\hline Water & 0.51 & $0.51(0.0)$ & $0.51(0.0)$ & $0.51(0.0)$ \\
Urban & 7.0 & $9.81(+22.68)$ & $10.01(+25.21)$ & $11.43(+42.94)$ \\
Forest & 31.23 & $29.99(-0.8)$ & $29.95(-0.92)$ & $29.76(-1.54)$ \\
Range & 4.79 & $4.71(-1.65)$ & $4.68(-2.3)$ & $4.6(3.81)$ \\
Pasture & 27.65 & $26.8(-3.08)$ & $26.73(-3.35)$ & $26.09(-5.65)$ \\
Agriculture & 25.18 & $24.54(-2.55)$ & $24.48(-2.78)$ & $24.02(-4.63)$ \\
Wetland & 3.65 & $3.65(0)$ & $3.65(0)$ & $3.59(-1.54)$ \\
\hline
\end{tabular}

alternative future scenarios create different patterns of LULC change in the FRW which was used to evaluate the hydrologic response to increases in different levels of urbanization.

\subsection{SWAT Data Inputs and Model Setup}

The spatially distributed data needed for the ArcSWAT interface include Digital Elevation Model (DEM), LULC, soil, weather, stream flow and sediment data. 


\subsubsection{Digital Elevation Model}

The DEM (Figure 3(a)) was retrieved from the National Elevation Dataset (NED) with 1/3-arc second (10-meter) resolution from the USGS Seamless Data Server [33]. The topographical data were used to delineate the watershed and sub-basins as the stream network, longest reaches, and drainage surfaces. The FRW was manually delineated using the DEM and the threshold of 1000 hectares as drainage area and was based on recommendations from other SWAT studies with similar watershed characteristics [36] [37]. This resulted in subdivision of the FRW into 84 sub-basins. The ArcSWAT interface allows the user to generate the stream network and outlets. For this analysis thirteen additional sub-basin outlets were manually added into the watershed based on the two known stream gage locations and the eleven known field site locations. The option to create multiple HRUs per sub-basin was enabled and generalized based on dominant land use, soil, and slope characteristics. This process generated 208 HRUs that were used as the basic hydrological units for the FRW.

\subsubsection{Land Use Land Cover}

The 2001 National Land Cover Dataset with a 30 meter resolution was downloaded from the USGS Seamless Data Server [33]. For use in SWAT, the LULC data set was reclassified into seven major land classes: water, residential, forest, range, pasture, agriculture and wetland (Figure 3(b)).

\subsubsection{Soil Data-Soil Survey Geographic Database (SSURGO)}

The soil map is important for accurate simulation of plant growth, water yield, sediment erosion, and nutrients cycling. The SSURGO data at 1:24,000 scale provides the highest resolution for a county-wide soil database. The data were downloaded from the USDA-NRCS Geospatial Data Gateway [34] (http://datagateway.nrcs.usda.gov/),
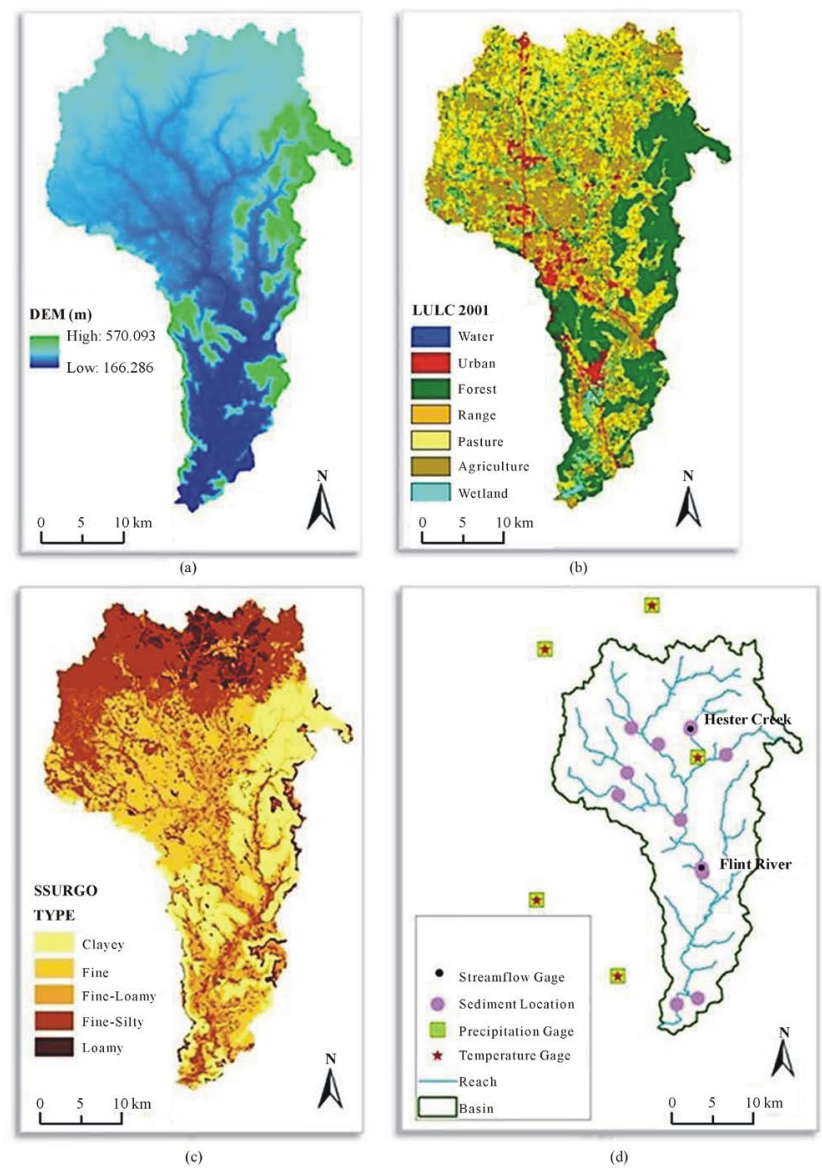

Figure 3. Basic spatial and weather data input (a) Digital Elevation Model (DEM) (b) land cover map (c) soil map (d) location of weather stations and field sites. 
geo-processed the dataset in a format compatible with ArcSWAT, append it to a user soil dataset, build a watershed specific soil lookup table, and create a soil GIS layer (Figure 3(c)).

\subsubsection{Weather Data}

To simulate regional weather, inputs of minimum and maximum daily temperatures as well as daily precipitation were required. The observation data of five weather stations (Figure 3(d)) were collected from the National Climatic Data Center (NCDC) for the years 2000-2010 [35]. While the future may not experience the same climate condition that were recorded for the region historically, this study assumes weather patterns for the decade long simulation period will mimic previous climate observations in the region and efforts to minimize variation in climate helped to exemplify the effects of LULC change.

\subsubsection{Stream Flow}

Mean stream flow data were collected from the USGS National Water Information System (NWIS) for the years 2000-2007 (calibration) and 2008-2010 (validation) at Hester Creek (USGS 0357479650) and at Flint River (USGS 03575100) stream gages (Figure 3(d)) [33]. The stream flow data were reformatted for use in the calibration and validation process.

\subsubsection{Sediment}

Turbidity in FTU (Formazin Turbidity Unit) was measured biweekly at eleven sites throughout the FRW in the spring, summer and fall of the years 2008-2010 (Figure 3(d)). Turbidity is caused by suspended material and is used to gauge water quality. This data was not used in the calibration process, but served as a validation that SWAT sediment predictions were acceptable when compared to observed data. To explore the accuracy of the sediment output, the observed turbidity data were converted to total suspended solids (TSS) in $\mathrm{mg} / \mathrm{L}$ to enable validation of the values from the SWAT model for the years 2008-2010. Conversion of FTU into $\mathrm{mg} / \mathrm{L}$ is required since turbidity was used as a surrogate for TSS because it can be measured immediately in the field. The turbidity/TSS relationship is interpreted by linear regression analysis. The data between suspended solids and turbidity from laboratory results was plotted and an interpolated equation derived. The relationship was $y=$ $1.4558 x$ with $\mathrm{R}^{2}=0.9693$, a simple straight line fit with a zero intercept.

Before the SWAT model can be run for monthly and daily simulations, the initial watershed input values must be defined. These values are set automatically based on the watershed delineation and land use, soil and slope characterization [17]. To build the initial values, the default Manning's roughness (n) value and heat units program was used to automatically calculate the channel flow in all sub-basins and the heat units required to reach maturity for different vegetation types. By selecting the default value of 0.014 for Manning's roughness factor and using the heat units program, ArcSWAT generated all the input files. This model was run for 11 years, starting on January $1^{\text {st }}$ of 2000 and ending on December $31^{\text {st }} 2010$. The first three years were not included in the output of the model since it was considered a "spin-up period" used to initialize the hydrologic cycle in the sub-basins. After calibration, the model was run again with the baseline year land use data and then with the three future land use scenarios for 2030.

\subsection{Calibration and Validation}

SWAT-CUP4 (Calibration and Uncertainty Programs) [36] was used for calibration and uncertainty analysis on stream flow parameters. SWAT-CUP is a public domain computer program for calibration of SWAT models. It links Generalized Likelihood Uncertainty Estimation (GLUE), Parameter Solution (ParaSol), Sequential Uncertainty Fitting, ver. 2 (SUFI-2), Markov Chain Monte Carlo (MCMC) and Particle Swarm Optimization (PSO) procedures to SWAT output files [36]. It enables sensitivity analysis, calibration, validation, and uncertainty analysis of a SWAT model. SUFI-2 algorithm [36] was used in this analysis for the calibration of the upstream gauge (Hester Creek) and downstream gauge (Flint River) for the monthly and daily SWAT runs. The available monthly and daily discharges at these two gauges covered the entire 11-year simulation period, however, the data were split into a calibration period of 2003-2007 and a validation period of 2008-2010 (The first three years were not included in the output of the model as described above). The Hester Creek gauge was located in sub-basin 19 and the Flint River gauge in sub-basin 62 of the delineated FRW (Figure 4).

In this analysis the physically meaningful parameter identifiers were chosen and the initial ranges were assigned to each flow parameter from the SWAT outputs. The SWAT-CUP format for parameter aggregation is: 


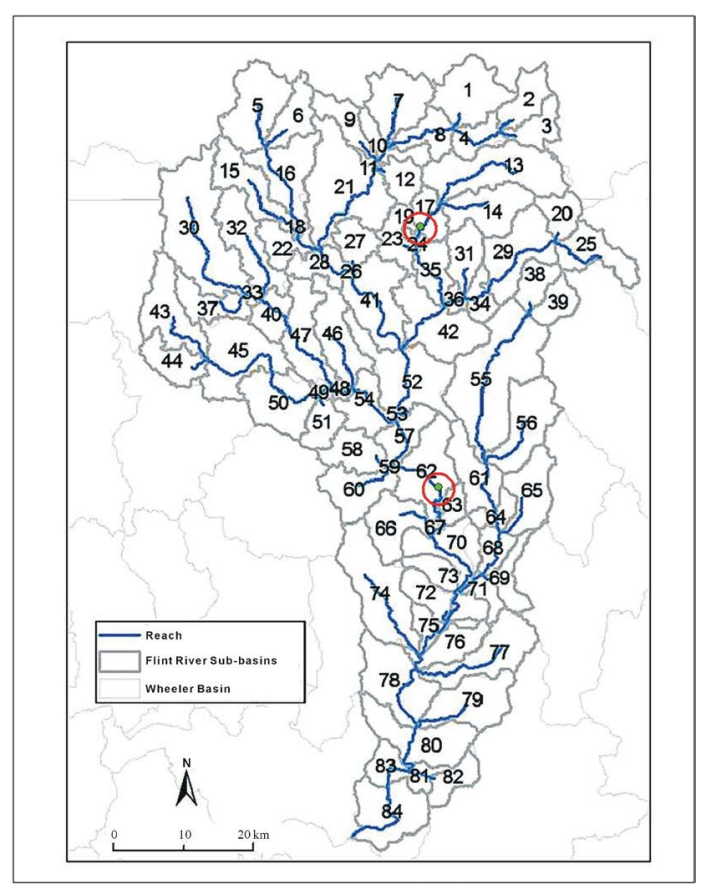

Figure 4. Map of delineated sub-basins within the Flint River watershed.

$\mathrm{x}_{\text {_ }}<$ parname $>$. $<\mathrm{ext}>$, where $\mathrm{x}$ _ is a code to indicate the type of change to be applied to the parameter (Abbaspour, 2011). The <parname $>$ is the SWAT parameter name and <ext $>$ is the SWAT file extension code for the parameter. Theparameters included in the calibration were chosen based on a one-at-a-time sensitivity analysis that varies one parameter while keeping all the others constant and a global sensitivity analysis that varies all parameters simultaneously [36]. The aim of sensitivity analysis is to estimate the rate of change in the output of a model with respect to changes in model input. Although more parameters could have been chosen to increase accuracy, only nine (Table 2) were selected in an effort to minimize calibration time and maximize model efficiency.

SUFI-2 was run for 500 iterations on the up-stream gage and then the down-stream gauge and the best simulated parameter values were used to edit the initial SWAT model run. The degree to which all uncertainties are accounted for is quantified by a measure referred to as the P-factor, which is the percentage of measured data bracketed by the $95 \%$ prediction uncertainty (95PPU). The best parameter values were selected based on whether the width of the uncertainty band (R-factor) was close to zero and the P-factor was close to one. The goodness-of-fit measures used to evaluate the models predictions included both the Nash-Sutcliffe (NS) [37] value and the coefficient of determination $\left(\mathrm{R}^{2}\right)$ value. The $\mathrm{R}^{2}$ value is an indicator of the strength of the relationship between the observed and simulated values and ranges from 0 to 1 . The NS simulation indicates how well these values fit the 1:1 line. If $\mathrm{R}^{2}$ and NS values are close to zero, the model is considered "unacceptable or poor" however if the values are 1.0 then the model is considered "perfect" [37]. ANS value of 0.5 or higher was considered an acceptable level of accuracy for this simulation based on a synthesis of existing peer-reviewed SWAT literature [23] [37].

Using the calibrated SWAT run for 2003-2007, the model was validated for flow by running it again for 2008-2010 as the validation period. The observed stream flow data at the two stream gages within the FRW for the 2008-2010 time periods were compared with that of the simulated stream flow values from the validation run. The validation was carried out using the $\mathrm{R}^{2}$ and NS coefficient.

\section{Results}

\subsection{Streamflow}

The results of monthly discharge calibration at Hester Creek and Flint River gauges are shown in Figure 5. While the flow patterns may not be exact, the calibrated simulation exhibits a more accurate range of minimum 

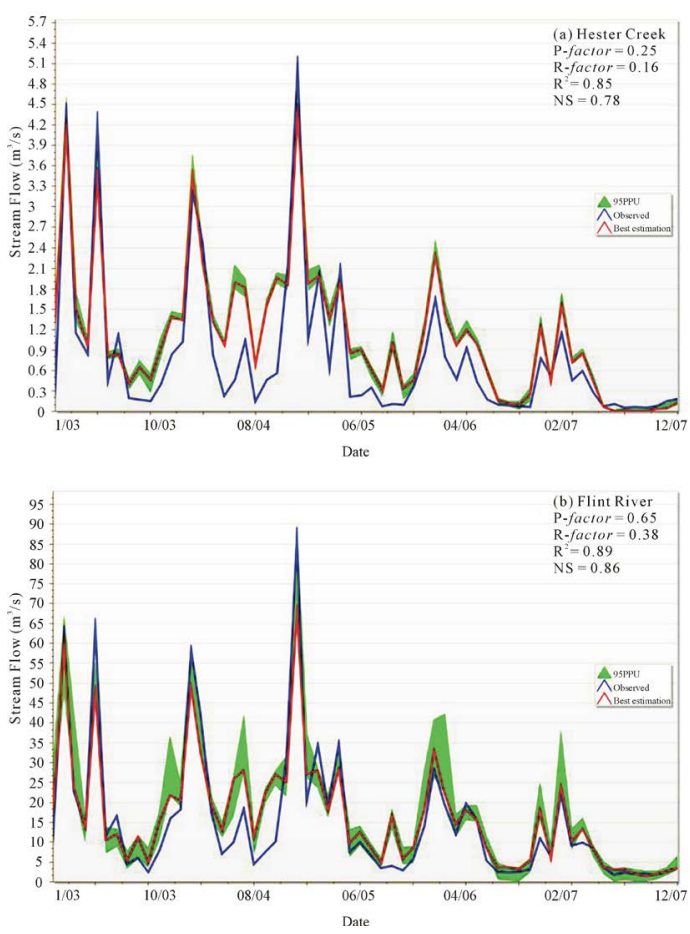

Figure 5. Monthly stream flow calibration-Flint River watershed (a) Hester Creek, and (b) Flint river.

Table 2. The SWAT model parameters included in the monthly calibration procedure and their final calibrated values for the up-stream gage $(1-9)$ and down stream $(10-18) .^{*} v_{\text {_ }}$ means the default parameter is replaced by a givern value, a _ means the parameter value is added to given value and $r_{\text {_ }}$ means the existing parameter value is multiplied by (1+ a given value).

\begin{tabular}{cccc}
\hline Parameter name & Description & Initial value & Final value \\
\hline a__GW_DELAY.gw & Groundwater delay time (days) & 31 & 162 \\
a_GW_REVAP.gw & Revap coefficient & 0.02 & 0.2 \\
a_GWQMN.gw & Threshold water level in aquifer (mm) & 0 & 2.5 \\
r_SOL_K.sol & Soil hydraulic conductivity (mm/hr) & 1.4 & 1.82 \\
r_SOL_AWC.sol & Soil available water storage capacity (mm/mm) & 0.21 & 0.39 \\
v_CH_N2.rte & Manning's n value for the channel & 0.014 & 0.26 \\
v_ALPHA_BNK.rte & Baseflow alpha factor for bank storage (days) & 0 & 0.3 \\
r_CN2.mgt & Curve number for moisture condition & 79 & 83.7 \\
v_ESCO.hru & Soil evaporation compensation factor & 0 & 0.62 \\
a_GW_DELAY.gw & Groundwater delay time (days) & 31 & 84 \\
a_GW_REVAP.gw & Revap coefficient & 0.02 & 0.2 \\
v_ALPHA_BF.gw & Baseflow alpha factor (days) & 0.048 & 1.0 \\
r_SOL_BD.sol & Soil bulk density (g/cm $\left.{ }^{3}\right)$ & 1.4 & 1.61 \\
r_SOL_AWC.sol & Soil available water storage capacity (mm/mm) & 0.17 & 0.19 \\
v__ALPHA_BNK.rte & Baseflow alpha factor for bank storage (days) & 0 & 0.66 \\
v_CH_K2.rte & Main channel conductivity (mm/hr) & 0 & 105.2 \\
r_CN2.mgt & Curve number for moisture condition & 78 & 74.8 \\
v_ESCO.hru & Soil evaporation compensation factor & 0 & 0.73 \\
\hline
\end{tabular}


and maximum values than the un-calibrated trail. An R-factor near zero generally indicates a good calibration result. This is evident for both stations, where the R-factor is relatively small. However, the P-factor for Hester Creek is too small, which indicates that the actual uncertainty is larger than that shown. This could have been improved upon at the expense of a larger R-factor. When examining daily calibration results for the USGS gauges in Figure 6 the accuracy decreases from the monthly time series.

When evaluating the simulations graphically, the accuracy of the model can be demonstrated clearly for the years 2003-2010 (Figure 7). For the monthly time series, $\mathrm{R}^{2}$ values were high with a value of 0.80 for Hester Creek and 0.88 for Flint River. The daily time series exhibited a much lower correlation between observed and simulated values, having an $\mathrm{R}^{2}$ of 0.68 for Hester Creek and 0.70 for Flint River. All of the time series had an acceptable level of accuracy with NS values higher than 0.5 . The validation was performed to evaluate the performance of the model with calibrated parameters to simulate the hydrological functioning of the watershed over a time period (2008-2010) that was not used in the calibration phase. Even though a longer data period is needed
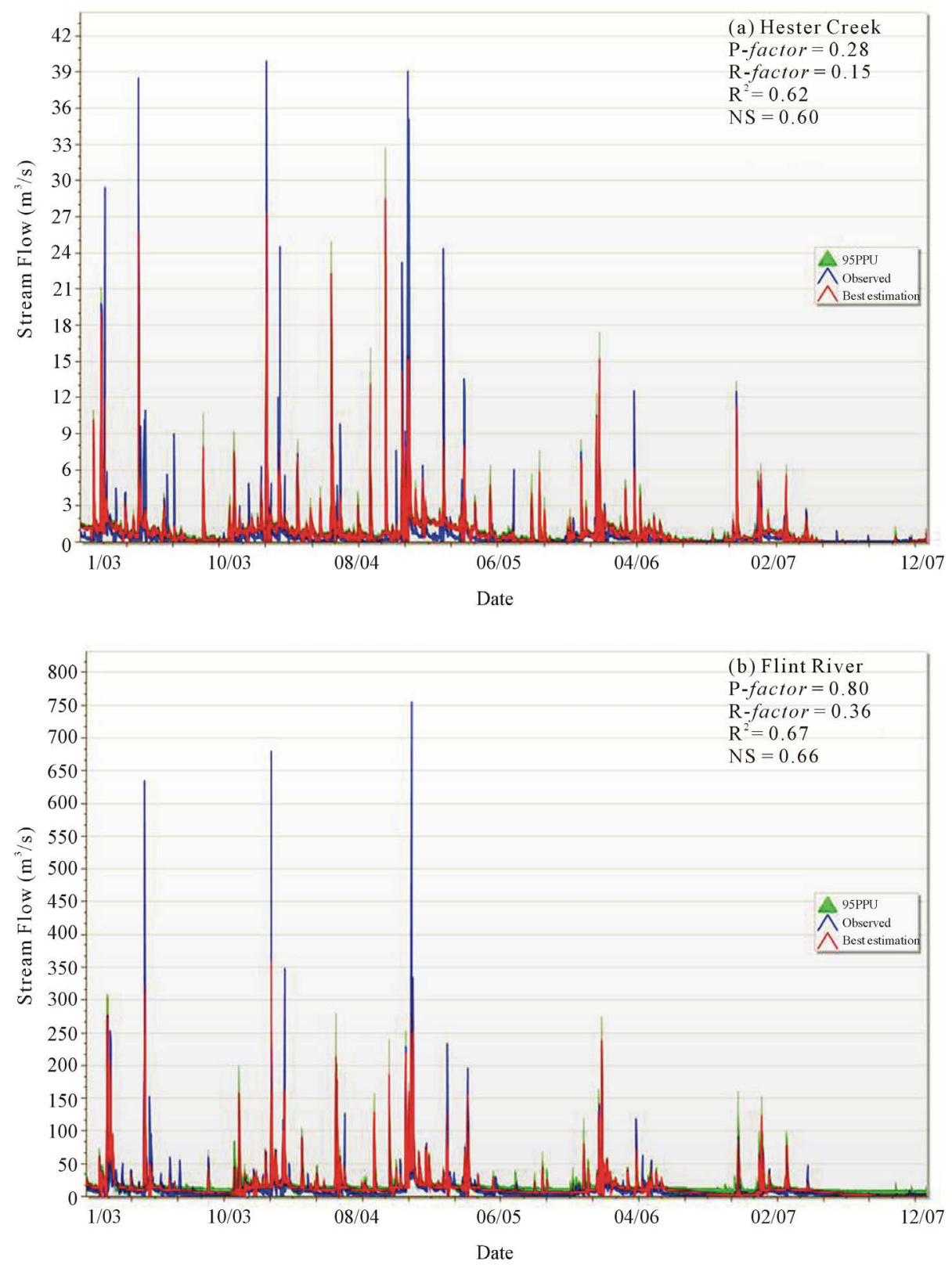

Figure 6. Daily stream flow calibration-Flint River watershed (a) Hester Creek, and (b) Flint river. 


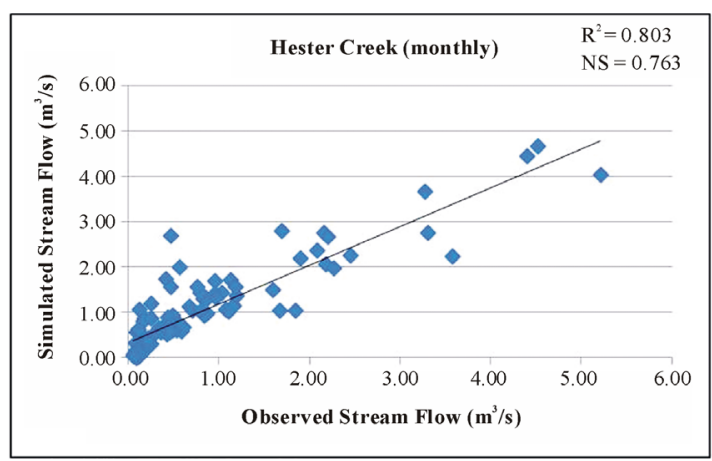

(a)

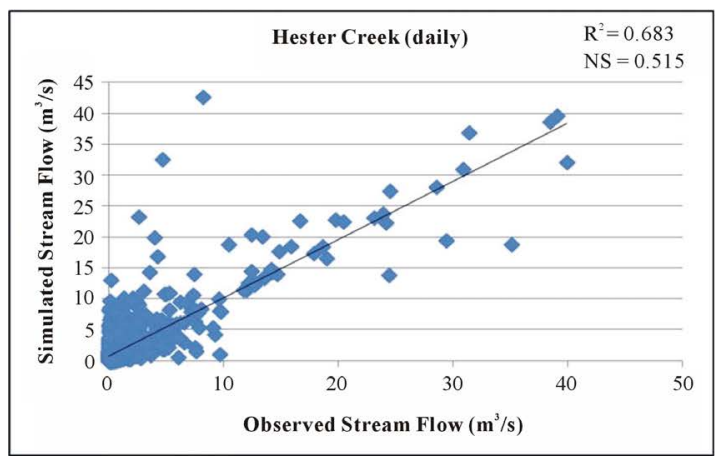

(c)

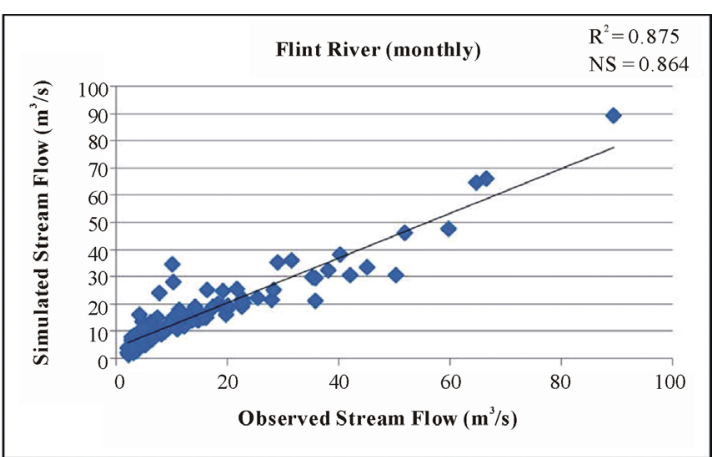

(b)

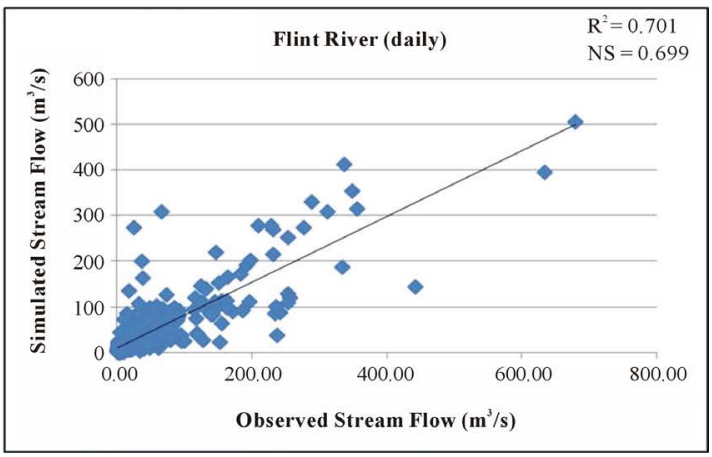

(d)

Figure 7. Comparison of monthly (a), (b)/daily (c), (d) observed and simulated streamflow for the calibration and validated period (2002-2010).

for better simulation the flow dynamic is quite well simulated for all stations on both time scales.

\subsection{Sediment}

To explore the accuracy of the sediment outputs, the observed turbidity samples were compared to the model simulated TSS values when run with the baseline land cover data. The observed data from field sampling at the eleven sites within the FRW was limited with only 107 turbidity observations over a three-year period of 2008-2010. All of the sampling was done in the spring, summer and fall and was converted to TSS. This conversion could be responsible for some of the differences in the accuracy of the sediment data. However, the model does a good job of simulating sediment transport with an $\mathrm{R}^{2}$ value of 0.71 and a NS value of 0.70 which can be seen in Figure 8 .

The sedimentation data was evaluated using the statistical measures of the NS coefficient and the $\mathrm{R}^{2}$, as shown in Table 3. Seven of the sites exhibited a strong association between observed and simulated data, while the other four (Beaverdam Creek, Hurricane Creek, Mountain Fork, and Yellow Bank) showed that there was significant differences between the model and observed values. The poor performance displayed in these sub-basins may be due to inaccurate turbidity observations that were converted to total suspended solids or the presence of fresh water springs within the sub-basins for which there was no available data to be used in the model.

Nonetheless, when analyzed as a whole the model appears to adequately simulate the sedimentation processes within the FRW.

\subsection{Comparison of Sediment Yield}

When the Smart, Plan, and Sprawl growth scenarios for 2030 were run in the calibrated SWAT model, the predicted total sediment yield increased $11.08 \%, 11.43 \%$ and $12.12 \%$, respectively, from the baseline calibrated model run. The total sediment yield was calculated by determining the average annual sediment value from 2003-2010 with the monthly time scale data. Monthly average sediment yields were separated by sub-basin and 


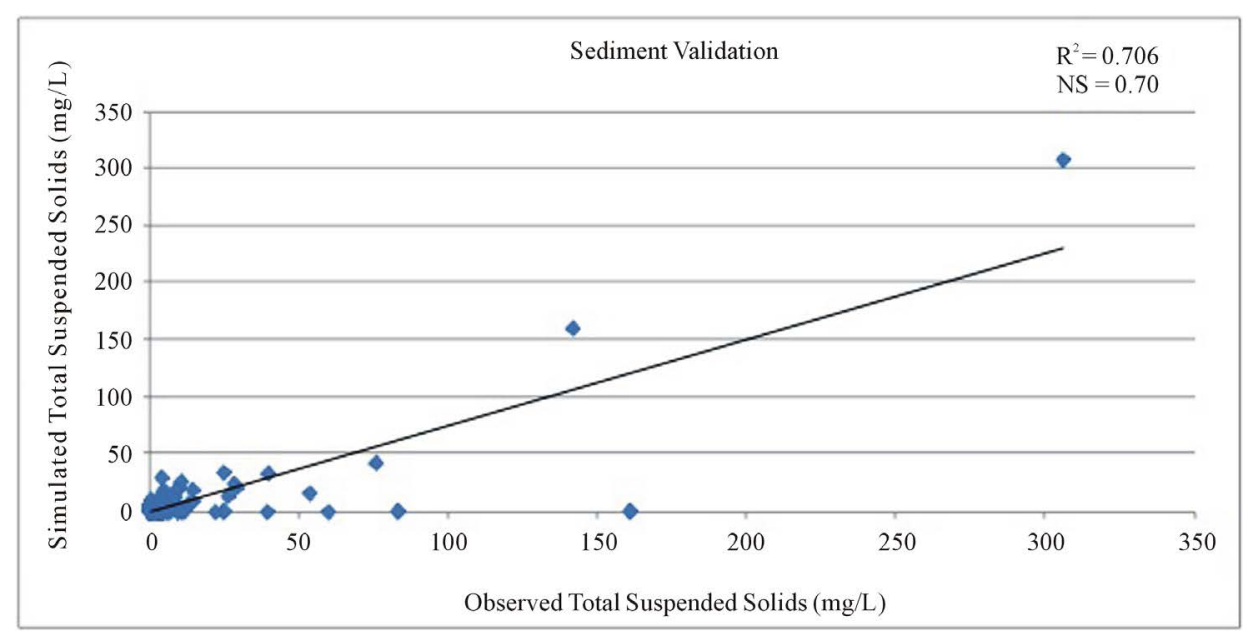

Figure 8. Comparison of daily observed and simulated total suspended solids (mg/L) for the Flint River watershed.

Table 3. Statistical evaluation of the turbidity measurements within the Flint River watershed.

\begin{tabular}{ccccc}
\hline Field Site & Samples & Sub-basin \# & NS & $\mathrm{R}^{2}$ \\
\hline Beaverdam Creek & 11 & 45 & 0.25 & 0.31 \\
Brier Fork WTARS & 5 & 40 & 0.59 & 0.69 \\
Hester Creek & 29 & 17 & 0.99 & 0.99 \\
Hurricane Creek & 9 & 61 & 0.12 & 0.18 \\
Keys Mill & 7 & 28 & 0.71 & 0.89 \\
Mountain Fork & 10 & 29 & 0.31 & 0.42 \\
Three Forks & 6 & 53 & 0.97 & 0.99 \\
Tolado Landing & 6 & 63 & 0.55 & 0.78 \\
West Fork & 7 & 18 & 0.42 & 0.56 \\
Yellow Bank & 11 & 82 & 0.07 & 0.10 \\
Brier Fork & 6 & 83 & 0.69 & 0.96 \\
\hline
\end{tabular}

summed to annual values and the eight yearly quantities were averaged to determine the average sediment yield per year during the chosen time interval as done in previous studies [38]. The baseline simulations produced an annual total sediment yield for the watershed of 6.31 tons/hectare while the smart growth had a total of 7.01 tons/hectare and the plan and sprawl had even larger yields of 7.04 tons/hectare and 7.08 tons/hectare respectively. The largest contributors to sediment yield were the sub-basins located close to the Huntsville City Limits and Owens Cross Roads, accounting for $5 \%-30 \%$ of the total sediment load. The three sub-basins shown in red remained the largest contributors under the smart and plan scenarios but the sprawl scenario added sub-basin number 52 with $5 \%$ of the total sediment yield (Figure 9). Sub-basin 52's contribution to sediment load increased in the sprawl growth scenario due to an increase in urban land cover within the sub-basin. The sub-basins that represented $1 \%-5 \%$ of the total sediment yield, shown in orange, varied in each future growth scenario but most remained the same as the baseline scenario.

The difference in total average sediment yield (tons/year), relative to the baseline land use scenario, was calculated for each sub-basin for the three future growth scenarios (Figure 10). Of the 84 sub-basins delineated, 8 are projected to have no change or a slight decrease in sediment yield in the smart and plan scenarios (Figure 10(a) and Figure 10(b)) and six sub-basins are expected to experience no change or a slight decrease in the 

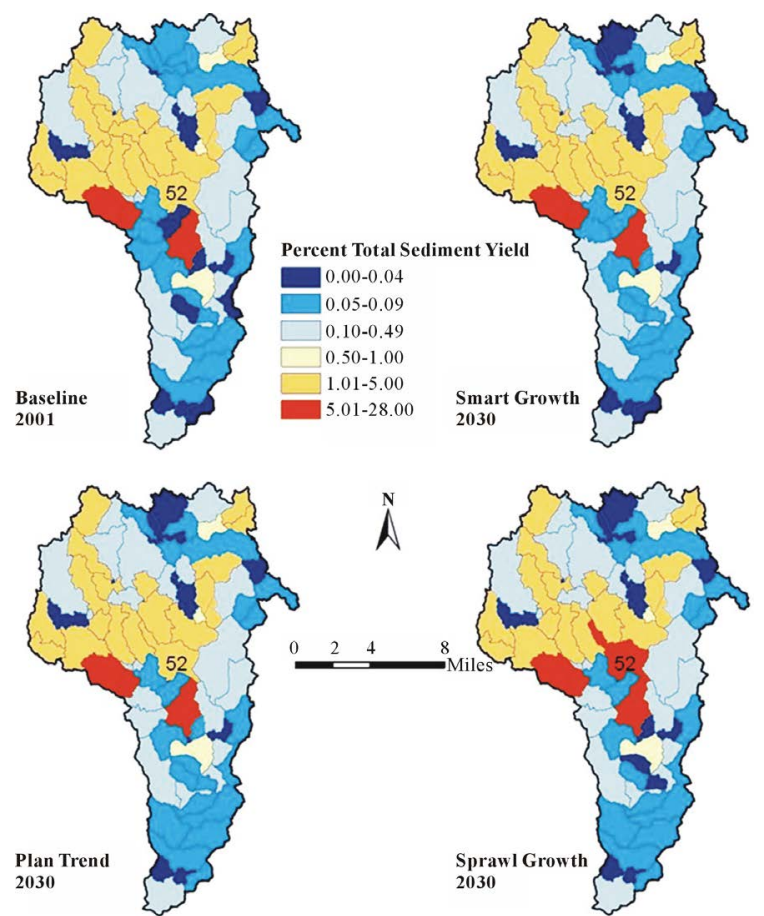

Figure 9. Percentage of total sediment yield for the Flint River watershed contributed by each sub-basin for baseline land use and future growth scenarios.

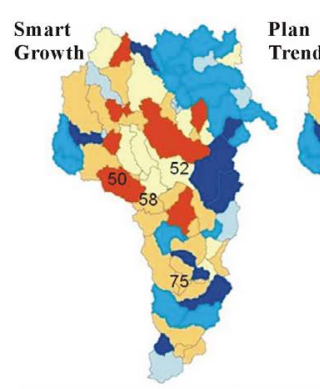

(a)

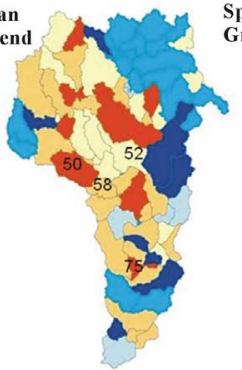

(b)

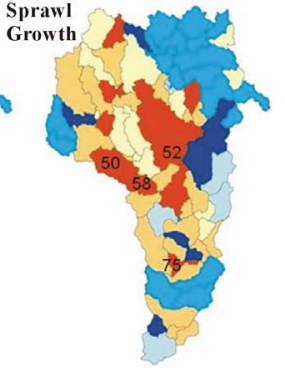

(c)

Relative Difference in Sediment Yield (tons/year) Development Scenarios Minus Baseline Scenario $-1.00-0.00$
$0.01-5.00$ $5.01-10.00$

$10.01-100.00$
$100.01-1,000.00$

$1,000.01-40.400 .00$
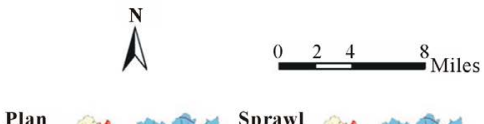

Smart
Growth

Plan
Trend

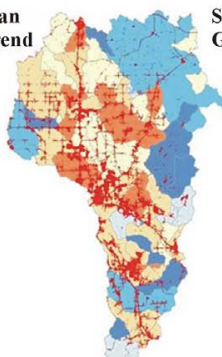

Sprawl Growth

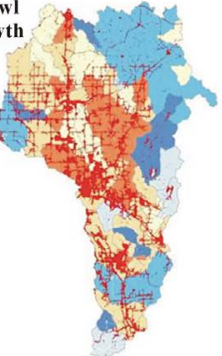

(d)

(f)

Figure 10. Relative change in sediment loading between (a) smart growth; (b) plan trend; (c) sprawl growth and baseline scenario and map of relative change in sediment overlaid with urban land use for (d) smart 2030; (e) plan 2030; and (f) sprawl 2030. 
sprawl scenario (Figure 10(c)). In the smart, plan and sprawl scenarios all of the other sub-basins show increases from the baseline sediment yield. The sub-basin with the largest increase in sediment yield was sub-basin number 50 in all three scenarios. There was no significant differences between the three scenarios and that the increase in sediment load was about 40 thousand tons in each. To clarify the relationship of sediment yield due to LULC change, the urban land use layer is shown for each scenario in Figures 10(d)-(f). In all the scenarios the sediment yield is higher in areas of intense urban development. The smart scenario (Figure 10(d)) and plan scenario (Figure 10(e)) were similar in development but the plan trend had more intense development in the Hampton Cove area in sub-basin 75. The sprawl scenario (Figure 10(f)) had more intense growth in sub-basin 58, bordering the Huntsville City Limits, and sub-basin 52 near the Brownsboro community.

Additionally, the relative percent difference was calculated for each sub-basin between the baseline and future scenarios. The largest percent increase in the difference between the baseline and smart scenario was $1.8 \%$ in sub-basin 41 which is located near the developing cities of Moores Mill and Meridianville, Alabama. The plan and sprawl scenarios displayed the largest percent increase also in sub-basin 41 with $1.82 \%$ and $1.84 \%$ respectively. Moreover, the largest decline in percent difference of $0.94 \%$ to $1 \%$ came from sub-basin 15 , located in the northwestern portion of the watershed in mostly Lincoln County, Tennessee for all three future scenarios. The comparison between scenarios of relative percent difference was generally small, although the overall increase of sediment for the watershed in the smart scenario was 101,138 tons/year. The plan scenario increased to 104,321 tons/year and the sprawl scenario increased to 110,623 tons/year from the baseline sediment yield.

To identify the critical sub-basins within the FRW, the results from the relative differences between scenarios are compared in Figure 11. For each future growth scenario the sub-basins with the largest increase in relative sediment loading (>1000 tons/yr) (Figure 11(a), Figure 11(d), Figure 11(g)) are indicated alongside the subbasins with the largest percent change (>0.04\%) (Figure 11(b), Figure 11(e), Figure 11(h)) to determine the sub-basins that should be prioritized as the most sensitive for sediment loading in the future. Therefore, the most critical sub-basins have both of the relative differences (largest increase and largest percent change in sediment loading) when overlaid. The sub-basins shown in red should be classified as having serious water quality issues and have management plans and planning policies placed to reduce and regulate sediment loading (Figure 11(c), Figure 11(f), Figure 11(i)) for the smart, plan and sprawl scenarios.

\section{Discussion}

Once the stream flow parameters were calibrated the monthly runs increased by $\sim 12 \%$ - 17\% and the daily model runs increased by $\sim 15 \%-20 \%$ in overall accuracy. Still the daily run showed the lowest accuracy of $\sim 68 \%$ $70 \%$, which may be due to inaccuracies in stream flow data or climate data and that monthly totals tend to smooth the data, which in turn increases the $\mathrm{R}^{2}$ value. Overall, visual inspection indicates simulated peak flow within the magnitude of the measured peak flows. However, simulated low flows sometimes were often higher than observed, which may be a result of the model's inability to predict the surface and sub-surface interaction associated with the karst topography [39]. LULC and topography define over land flow pathways and associated sediment mobilization and transport. Change in LULC to urban will increase overland flow and peak flows but this does not lead to an increase of the total stream flow discharge [39]. Higher peak flows increase the waters sediment transport capacity that can lead to stream degradation. If the slope of the stream remains the same an increase in stream flow discharge will lead to degradation because the sediment load will need to increase to maintain dynamic equilibrium [39]. The sediment yield simulated by the model had an accuracy of $70 \%$ with a large dispersion in the range between $0-160 \mathrm{mg} / \mathrm{L}$ and an NS value of 0.70 . The accuracy could be improved by using a longer period of observed data to calibrate for sediment. Previous research has had the same findings with SWAT model simulation of discharge being better than that of sediment transport. Although the model underestimated and overestimated daily discharge and suspended sediment for some flood events, predictions were within acceptable limits.

The SWAT model results indicate that hydrologic response in the Flint River watershed may be altered to favor increased average annual sediment yield due to LULC change during the period from 2001 to 2030, and consequently is at risk for decreased water quality and related impacts to the local ecology. Specifically, the assessment suggests that with an approximate $23 \%$ increase in urban development in the smart scenario, an approximate $11.08 \%$ increase in turbidity will occur within the FRW. For the plan scenario urban development increased by $\sim 25 \%$ and sediment yield increased by $\sim 11.43 \%$. The sprawl scenario had the largest increase in 


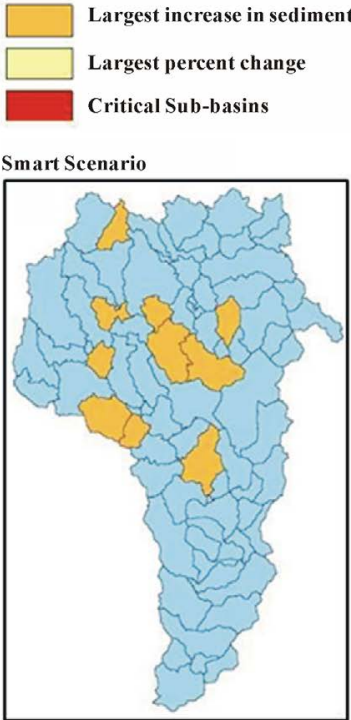

(a)

Plan Scenario

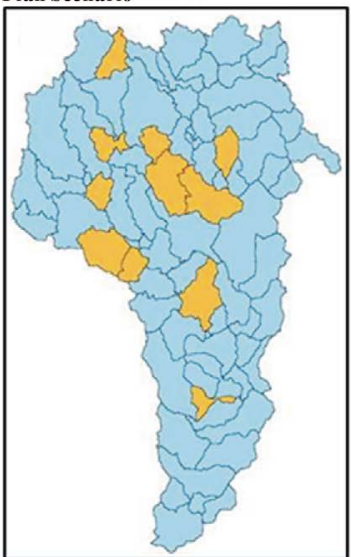

(d)

Sprawl Scenario

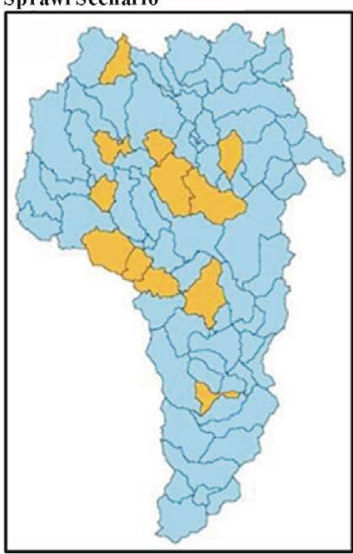

(g)
$\Lambda$

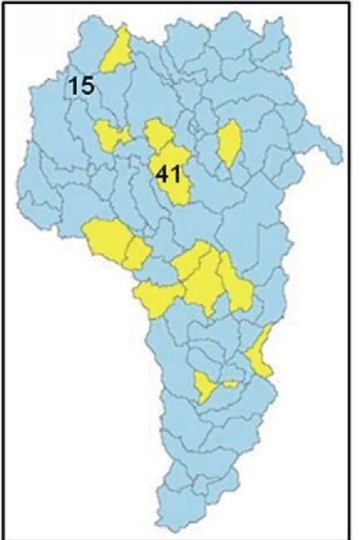

(b)

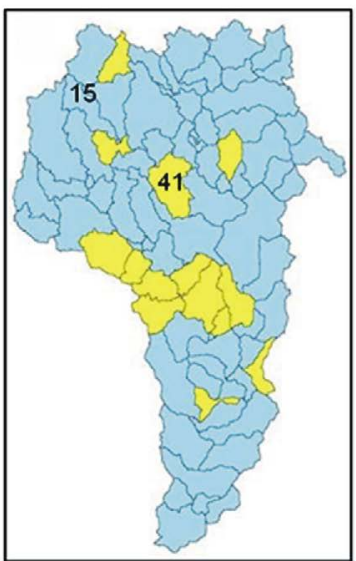

(e)

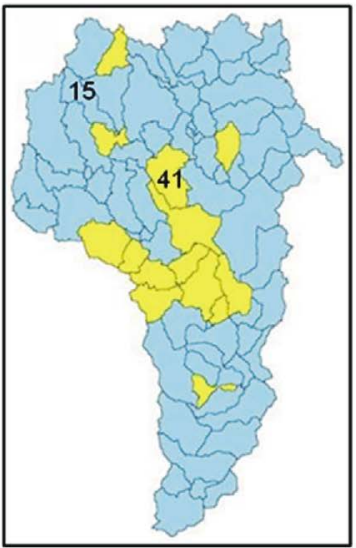

(h)
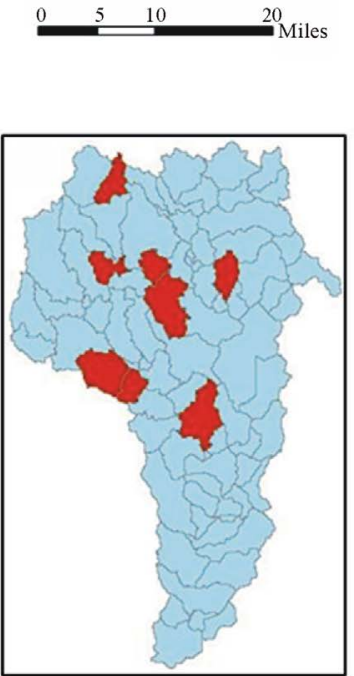

(c)

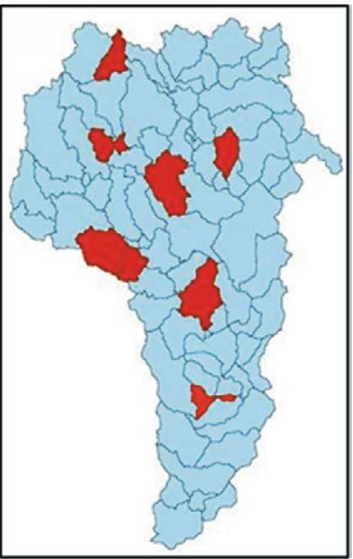

(f)

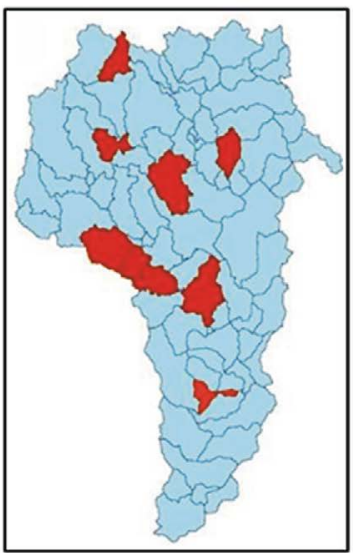

(i)

Figure 11. Summary of sediment yield for the Flint River sub-basins illustrating (a), (d), (g) the largest increase in relative sediment loading, (b), (e), (h) the largest percent change and (c), (f), (i) the most sensitive sub-basins to sediment loading for the different scenarios. 
urban land use of $\sim 43 \%$ and the largest increase in sediment yield of $12.12 \%$. The simulation results indicate that LULC changes associated with future urbanization will have a slight impact on turbidity. The increases in percent of sediment yield between the different scenarios suggest that the change from non-developed land to urban development has direct influence on sediment erosion.

\section{Conclusions}

Land-hydrologic models have proven to be efficient tools to meet the increasing demand for quantitative information on water availability and quality especially in response to changes in land-use, land management or climate. The hydrologic impact resulting from three future growth scenarios for the FRW was evaluated using SWAT, a deterministic hydrologic model that can predict hydrologic conditions over various temporal and spatial scales. In general, the future growth scenarios simulation results indicate that LULC changes associated with potential future urbanization will alter the hydrology of the study area. The most significant hydrologic impact was associated with increasing coverage of impervious surfaces and development. Although the sprawl growth scenario had the greatest negative impact, it should be noted the results were spatially variable and that negative results are likely under all three future growth scenarios as a result of predicted urbanization. Using sub-watersheds as the comparative unit, the comparative analyses are facilitated by summarizing simulation results graphically in terms of percent change relative to the baseline conditions for each of the scenarios.

This study found that increased urbanization resulted in increases in sediment yield indicating that developed lands are contributing to erosion. Watershed managers should take this into account when creating a management plan because sediment can bind with pesticides and other chemicals traveling down-stream and contaminate the water. Furthermore, increased sediment within the surface water is extremely costly to remove in the water purification process. Moreover, the critical sub-basins within each future scenario should be prioritized in future management plans based on their sensitivity to increases in sedimentation. While water resources are abundant, they are not unlimited; they must be carefully managed to meet long-term needs.

\section{Acknowledgements}

The authors gratefully acknowledge Drs. David Mays and Dawn Lemke for thorough review of this manuscript. We also thank Heather Howell, Allison Bohlman, Helen Czech, Dr. Raghavan Srinivasan, Mr. Hoyt Johnson and Mr. Howard Ward for their endless support of information pertaining to the research. Also, the United States Department of Agriculture, National Institute of Food and Agriculture Award No. 2008-51130-04899 and National Aeronautics and Space Administration Graduate Student Research Program Fellowship for their financial support to complete this work.

\section{References}

[1] Ma, X., Xu, J.C., Luo, Y., Prasad Aggarwal, S. and Jiatong, L. (2009) Response of Hydrological Processes to Land-Cover and Climate Changes in Kejie Watershed, Southwest China. Hydrological Processes, 23, 1179-1191. http://dx.doi.org/10.1002/hyp.7233

[2] Walsh, C., Fletcher, T.D. and Ladson, A.R. (2005) Stream Restoration in Urban Catchments through Redesigning Storm-Water Systems: Looking to the Catchment to Save the Stream. Journal of the North American Benthological Society, 24, 690-705. http://dx.doi.org/10.1899/04-020.1

[3] Wischmeier, W.H. and Smith, D.D. (1978) Predicting Rainfall Erosion Losses-A Guide to Conservation Planning. USDA Agricultural Handbook, 537, US Gov. Print. Office, Washington DC, 4.

[4] Tennessee Valley Authority, Madison County Natural Resources Conservation Service, and Madison County Watershed Advisory Committee (2008) Flint River Watershed Management Plan. Revised May 2008.

[5] Nelson, E.J. and Booth, D.B. (2002) Sediment Sources in an Urbanizing, Mixed Land-Use Watershed. Journal of Hydrology, 264, 51-68. http://dx.doi.org/10.1016/S0022-1694(02)00059-8

[6] Schoonover, J.E., Lockaby, B.G. and Pan, S. (2005) Changes in Chemical and Physical Properties of Stream Water Across an Urban-Rural Gradient in Western GEORGIA. Urban Ecosystems, 8, 107-124. http://dx.doi.org/10.1007/s11252-005-1422-5

[7] Krause, C.W., Lockhard, B., Newcomb, T.J., Kibler, D., Lohani, V. and Orht, D.J. (2004) Predicting Influences of Urban Development on Thermal Habitat in a Warm Water Stream. Journal of the American Water Resources Association, 40, 1645-1658. http://dx.doi.org/10.1111/j.1752-1688.2004.tb01612.x 
[8] Berry, W., Rubinstein, N., Melzian, B. and Hill, B. (2003) The Biological Effects of Suspended and Bedded Sediment (SABS) in Aquatic Systems: A Review. US Environmental Protection Agency, Office of Research \& Development.

[9] Environmental Protection Agency (2006) Contaminated Sediment in Water. Viewed 18 August 2010. http://www.epa.gov/waterscince/cs/aboutcs/sources.html. 27 February 2006

[10] Fohrer, N., Haverkamp, S. and Frede, H.G. (2005) Assessment of the Effects of Land Use Patterns on Hydrologic Landscape Functions: Development of Sustainable Land Use Concepts for Low Mountain Range Areas. Hydrological Processes, 19, 659-672. http://dx.doi.org/10.1002/hyp.5623

[11] Siriwardena, L., Finlayson, B.L. and McMahon. T.A. (2006) The Impact of Land Use Change on Catchment Hydrology in Large Catchments: The Comet River, Central Queensland, Australia. Journal of Hydrology, 326, 199-214. http://dx.doi.org/10.1016/j.jhydrol.2005.10.030

[12] Zhang, Y.K. and Schilling, K.E. (2005) Increasing Streamflow and Baseflow in Mississippi River since the 1940s: Effect of Land Use Change. Journal of Hydrology, 324, 412-422. http://dx.doi.org/10.1016/j.jhydrol.2005.09.033

[13] Lin, Y.P., Hong, N.M., Wu, P.J., Wu, C.F. and Verburg, P.H. (2007) Impacts of Land Use Change Scenarios on Hydrology and Land Use Patterns in the Wu-Tu Watershed in Northern Taiwan. Landscape and Urban Planning, 80, 111-126. http://dx.doi.org/10.1016/j.landurbplan.2006.06.007

[14] Franczyk, J. and Chang, H. (2009) The Effects of Climate Change and Urbanization on the Runoff of the Rock Creek Basin in the Portland Metropolitan Area, Oregon, USA. Hydrological Processes, 23, 805-815. http://dx.doi.org/10.1002/hyp.7176

[15] Im, S., Kim, H., Kim, C. and Jang, C. (2009) Assessing the Impacts of Land Use Changes on Watershed Hydrology Using MIKE SHE. Environmental Geology, 57, 231-239. http://dx.doi.org/10.1007/s00254-008-1303-3

[16] Winchell, M., Srinivasan, R., Di Luzio, M. and Arnold, J.G. (2009) ArcSWAT 10.1 Interface for SWAT2010, Users Guide, Version September 2009. Texas Agricultural Experiment Station and Agricultural Research Service, US Department of Agriculture, Temple.

[17] Arnold, J.G., Srinivasan, R., Muttiah, R.S. and Williams, J.R. (1998) Large Area Hydrologic Modeling and Assessment Part I: Model Development. Journal of the American Water Resources Association, 34, 73-89. http://dx.doi.org/10.1111/j.1752-1688.1998.tb05961.x

[18] Fadil, A., Rhinane, H., Kaoukaya, A., Kharchaf, Y. and Bachir, O.A. (2011) Hydrologic Modeling of the Bouregreg Watershed (Morocco) Using GIS and SWAT Model. Journal of Geographic Information System, 3, 279-289. http://dx.doi.org/10.4236/jgis.2011.34024

[19] Neitsch, S.L., Arnold, J.G., Kiniry, J.R. and Williams, J.R. (2009) Soil and Water Assessment Tool Theoretical Documentation-Version 2009. Soil and Water Research Laboratory, Agricultural Research Service, US Department of Agriculture, Temple.

[20] Williams, J.R. and Berndt, H.D. (1977) Sediment Yield Prediction Based on Watershed Hydrology. Transactions of the American Society of Agricultural and Biological Engineers, 20, 1100-1104. http://dx.doi.org/10.13031/2013.35710

[21] Gassman, P.W., Reyes, M.R., Green, C.H. and Arnold, J.G. (2007) The Soil and Water Assessment Tool: Historical Development, Applications and Future Research Directions. Transactions of the American Society of Agricultural and Biological Engineers, 50, 1211-1250. http://dx.doi.org/10.13031/2013.23637

[22] Santhi, C., Arnold, J.G., Williams, J.R., Dugas, W.A., Srinivasan, R. and Hauck, L.M. (2001) Validation of the SWAT Model on a Large River Basin with Point and Nonpoint Sources. Journal of the American Water Resources Association, 37, 1169-1188. http://dx.doi.org/10.1111/j.1752-1688.2001.tb03630.x

[23] Tripathi, M., Rghuwanshi, N. and Rao, G. (2006) Effect of Watershed Subdivision on Simulation of Water Balance Components. Hydrological Processes, 20, 1137-1156. http://dx.doi.org/10.1002/hyp.5927

[24] Gosain, A., Rao, S., Srinivasan, R. and Reddy, N. (2005) Return-Flow Assessment for Irrigation Command in the Palleru River Basin Using SWAT Model. Hydrological Processes, 19, 673-682. http://dx.doi.org/10.1002/hyp.5622

[25] Cao, W., Davie, T., Bowden, W. and Fenemor, A. (2006) Multi-Variable and Multi-Site Calibration and Validation of SWAT in a Large Mountainous Catchment with High Spatial Variability. Hydrological Processes, 20, 1057-1073. http://dx.doi.org/10.1002/hyp.5933

[26] Environmental Protection Agency (2010) Our Built and Natural Environments: A Technical Review of the Interactions between Land Use, Transportation, and Environmental Quality.

[27] Geological Survey of Alabama (2010) Hydrogeology: Alabama Water Facts. http://www.gsa.state.al.us/gsa/hydrogeology/justfacts.html

[28] U.S. Department of Commerce Bureau of the Census, Population Estimates Division. 14 August 2010.

[29] Laymon, C. (2003) Environmental Assessment at County Scale. http://wwwghcc.msfc.nasa.gov/land/ncrst/ca.html

[30] Houghton, J., Ding, Y., Griggs, D.J., Noguer, M., van der Linden, P.J., Dai, X., Maskell, K. and Johnson, C., Eds., Intergovernmental Panel on Climate Change (IPCC) (2001) Climate Change 2001: The Scientific Basis. Contribution of 
Working Group I to the Third Assessment Report of the Intergovernmental Panel on Climate Change, Cambridge University Press, Cambridge, 881 p.

[31] Estes, M.G., Crosson Jr., W., Johnson, H. and Quattrochi, D. (2007) Validation and Demonstration of the Prescott Spatial Growth Model in the Atlanta, Georgia. International Symposium on Remote Sensing and Environment, San Jose, 25-29 June 2007.

[32] Kepner, W., Hernandez, M., Semmens, D. and Goodrich, D. (2008) The Use of Scenario Analysis to Assess Future Landscape Change on a Watershed Condition in the Pacific Northwest (USA). In: Petrosillo, I., et al., Eds., Use of Landscape Sciences for the Assessment of Environmental Security, Springer, Amsterdam, 237-261.

[33] United States Geological Survey (USGS) (2010) Seamless Server Data Warehouse. http://seamless.usgs.gov/

[34] USDA-NRCS Geospatial Data Gateway. http://datagateway.nrcs.usda.gov/

[35] NOAA (2010) Weather and Climate Toolkit. http://www.ncdc.noaa.gov/oa/wct/data.php

[36] Abbaspour, K.C. (2011) SWAT-CUP4: SWAT Calibration and Uncertainty Programs-A User Manual. Department of Systems Analysis, Swiss Federal Institute of Aquatic Science and Technology, Dübendorf.

[37] Nash, J.E. and Sutcliffe, J.V. (1970) River Flow Forecasting through Conceptual Models, Discussion of Principles. Journal of Hydrology, 10, 282-290. http://dx.doi.org/10.1016/0022-1694(70)90255-6

[38] Conaghan, K. (2010) Assessing the Hydrologic Implications of Land Use Change for the Upper Neuse River Basin. Master's Thesis, Duke University, Durham.

[39] Chaplot, V., Saleh, A., Jaynes, D.B. and Arnold, J. (2004) Predicting Water, Sediment and $\mathrm{NO}_{3}-\mathrm{N}$ Loading under Scenarios of Land-Use and Management Practices in a Flat Watershed. Water, Air, and Soil Pollution, 154, 271-293. http://dx.doi.org/10.1023/B:WATE.0000022973.60928.30 